\title{
Inside the Growth Machine: Real Estate Professionals on the Perceived Challenges of Urban Development
}

\author{
Shelley McDonough Kimelberg* \\ Department of Sociology E Anthropology, Northeastern University
}

\begin{abstract}
The growth machine framework maintains that coalitions of elites work together to promote and adopt policies and practices that best serve their economic interests and propel cities toward growth. While numerous scholars have subjected the growth machine to theoretical and empirical tests, we know little about the beliefs and perspectives of individual actors within the growth machine. To address this gap in the literature, the present research uses in-depth interviews to examine the subjective views of one segment of the growth machine-real estate professionals. The findings demonstrate that these practitioners see the exercise of power at the local level to be less coordinated, consensus-driven, and growth-oriented than the growth machine thesis suggests. Specifically, they see their own power and capacity to act to be constrained by four factors: the (re)-election interests of politicians; the professional interests of municipal economic development staff; bureaucratic procedures and zoning regulations; and mobilized community members and groups. I conclude with a discussion of the implications for urban political theory and suggestions for future research.
\end{abstract}

\section{INTRODUCTION}

For decades, social scientists have studied why, how, to what extent, and at what cost cities are shaped and changed. In detailing these processes, arguments have alternately emphasized the influence wielded by elected officials, mobilized citizens, community organizations and institutions, business leaders, municipal staff, real estate professionals, and other public and private sector actors. While numerous models of the urban power landscape have emerged from this discourse, among the most recognizable and widely cited is the "growth machine" thesis (Molotch, 1976; Logan and Molotch, 2007).

In his seminal article introducing the concept, Molotch (1976) argued that coalitions of pro-growth elites-i.e., corporations, the real estate community, government officials, and the media-work together to promote and adopt policies and practices that best serve their economic interests, and ultimately propel cities toward growth. While Molotch himself has acknowledged that growth machines face constraints in exercising their will (Molotch, 1988), the image of a closely aligned, omnipotent partnership between local

\footnotetext{
*Correspondence should be addressed to Shelley McDonough Kimelberg, Assistant Professor of Sociology, 535 Holmes Hall, 360 Huntington Avenue, Boston MA 02115; s.kimelberg@neu.edu.
}

City $\mathcal{E}$ Community 10:1 March 2011

doi: $10.1111 /$ j.1540-6040.2010.01351.x

(C) 2011 American Sociological Association, 1430 K Street NW, Washington, DC 20005 
public and private elites persists in our consciousness to such an extent that the beliefs and perspectives of the actors in the growth machine are often assumed to be consonant, and thus left largely unexamined. Indeed, as Logan and Crowder (2002) note, "More attention has been given to studying the opponents of growth. That is, many researchers take for granted the omnipresence of growth promoters and define their research question as the degree to which their initiatives are contested by other actors" (p. 115).

This tendency is certainly understandable. Given, for example, the devastating impact of many urban renewal initiatives in the United States on poor, working-class, and minority communities (see Rossi and Dentler, 1961; Gans, 1962; Stone, 1976; Mollenkopf, 1983; Logan and Molotch, 2007), it seems not only logical, but also morally imperative, that researchers strive to give voice to those individuals whose rights have often been ignored, or purposely subordinated, in the pursuit of expansion or profit. Recognizing this, however, does not obviate the need to examine how those presumed to be in power understand their position and capacity in the development process. The subjective perceptions of elite actors matter because, at some level, they influence how these individuals behave in the urban development process.

This research explores how members of one core segment of the growth machinereal estate professionals-view urban development. Specifically, I draw on in-depth interviews with developers and other real estate practitioners to address the following research question: What do decision makers in the private sector see as the challenges of urban development? For example, do business leaders and real estate executives typically find their interests aligned with those of local government officials, or are these public-private relationships more commonly contentious? How do real estate professionals view the role of "the community," those who are often assumed to oppose the growth machine monolithically in their pursuit of use values over exchange values? The intent is not to provide an empirical test of the growth machine thesis, as there exists a substantial literature devoted to examining the theory's explanatory power and generalizability (see, e.g., Lyon et al., 1981; Krannich and Humphrey, 1983; Canan and Hennessy, 1989; Cox and Mair, 1989; Schneider, 1992; Schneider and Teske, 1993; Jonas and Wilson, 1999; Gill, 2000; Humphrey, 2001). Rather, the objective is to understand how these purportedly dominant participants in the growth machine think about urban development, and in particular, what they identify as the constraints and checks on their power in the process of establishing a business in the city.

While other researchers have considered the degree to which any growth machine must navigate certain obstacles or negotiate with other interest groups (see, for instance, Cummings, 1988; Molotch, 1988; Logan, Whaley, and Crowder, 1997), the present study differs in two important respects. First, it offers a qualitative account of the perceptions and beliefs of real estate professionals, gleaned from the individuals themselves. While there are some good analyses of survey data in the literature (e.g., Rubin, 1986; Clingermayer and Feiock, 1990; Clark and Goetz, 1994), most capture the views of local public officials as opposed to private sector actors. Furthermore, such studies typically focus on a narrow set of quantifiable metrics that measure the degree to which businesses are involved in, or exert their influence on, development efforts. In contrast, surprisingly few attempts have been made by social scientists to capture the subjective views of business actors engaged in local development. Elkins' (1995) study of chambers of commerce in the United States, while based primarily on survey data, is noteworthy for its explicit focus on understanding how members of the local business community perceive the roles 
that various actors play in their city's development activities. Wood's $(1993,1996)$ study of four Ohio municipalities, and Fainstein's (2001) comparative research in New York and London likewise feature in-depth interviews with a number of private sector individuals, including business leaders, financial officers, and developers. However, it is more often the case that the perceptions and beliefs of such actors are taken as given, rather than made the topic of inquiry. ${ }^{1}$

Second, by utilizing interview data from real estate professionals engaged in development efforts throughout the United States, this work represents a clear departure from the case study approach employed nearly universally in research on the politics and practice of urban development (see, e.g., Fainstein, 2001; Hartman, 2002; Horak, 2007; Gendron and Domhoff, 2009). This methodology choice allows for variation in both geography and project type that is typically not possible in studies of a single municipality or development project, and which enhances the robustness and generalizability of the findings. While I do not undertake an analysis of the sources or consequences of these variations in the present article, the data appear to support what other researchers have noted about the extent to which growth machines are likely to differ in their composition, function, and capacity (Jonas and Wilson, 1999).

In the section that follows, I provide a brief review of the literature designed to situate the growth machine thesis in the expansive intellectual discourse on urban politics in the United States. I then describe my research design and methods. The remainder of the paper I devote to an analysis and discussion of urban development as viewed through the eyes of real estate professionals. I explore how these actors think about the process of siting commercial real estate, the specific interests and concerns that influence their beliefs, and how their beliefs are shaped by interactions and relationships with other actors, most notably local officials and community members. In doing so, I highlight what real estate professionals see as four distinct checks or limitations on their ability to establish commercial properties in urban areas: (1) the (re)-election interests of politicians; (2) the professional interests of economic development staff; (3) bureaucratic procedures and zoning regulations; and (4) mobilized community members and groups. I conclude with a brief discussion of the implications of this research for our understanding of urban development, as well as suggestions for future study in this area.

\section{POWER AND POLITICS IN URBAN THEORY}

In their comprehensive review of the literature on urban politics and development, Logan, Whaley, and Crowder (1997) note that part of the reason why the growth machine thesis caught the attention of so many scholars upon its introduction was that it engaged-even challenged-widely accepted paradigms in both political science and urban sociology. On the one hand, it forced a reconsideration of the pluralist model of urban governance in which power was said to be dispersed among many actors. At the same time, it took issue with the human ecology framework adopted by many sociologists, arguing that the free market assumptions implicit in its conception of urban development failed to account for the critical role that powerful individuals and groups play in shaping cities (Molotch, 1976).

Specifically, Molotch (1976) maintained that "the political and economic essence of virtually any locality, in the present American context, is growth... the desire for growth 
provides the key operative motivation towards consensus for members of politically mobilized local elites, however split they might be on other issues, and that a common interest in growth is the overriding commonality among important people in a given locale" (p. 310). This depiction of a coalition of powerful actors unified around their desire to direct resources (both financial and political) toward a shared goal of land development reflected a shift away from the decentralization of power in American cities described by pluralists such as Dahl (1961). In his classic case study of New Haven, Dahl highlighted the extent to which influence in the city was largely fragmented and specialized, restricted to particular spheres which, in turn, reflected particular interests. As some scholars have noted, the central concern motivating Dahl's emphasis on pluralism was the refutation of a single-elite model of urban power (Fainstein, 2001). Thus, the question of to what end that power was used was of secondary importance.

By arguing that, in fact, one could identify a core group of elite actors joined in a common goal, Molotch necessarily drew attention to the intended target of their focus: growth (Logan, Whaley, and Crowder, 1997). In doing so, he advocated a political economy perspective on the city that, in keeping with the work of Harvey (1973) and Castells (1977), refused to see urban change as a "natural" evolution dictated by market forces. Rather, he maintained that competition and conflict were the hallmarks of urban development—indeed, the drivers of it-and that deepening inequality within (and across) cities was the likely result (Logan and Molotch, 2007).

The emergence of regime theory in the 1980s broadened the discourse around power and the capacity to govern (Fainstein and Fainstein, 1983; Elkin, 1987; Stone, 1989). Positing that a growth coalition is merely one of several possible kinds of coalitions that may emerge in cities, and that coalitions, in general, shift and morph in response to historical and geographic factors, early proponents of the theory set about mapping distinct typologies of urban regimes (Lauria, 1997). For example, Fainstein and Fainstein's (1983) categories of directive, concessionary, and conserving regimes and Elkin's (1987) pluralist, federalist, and entrepreneurial regimes reflected a growing concern with identifying "how and under what conditions ... different types of governing coalitions emerge, consolidate, and become hegemonic or devolve and transform" (Lauria, 1997, p. 1-2).

In Regime Politics (1989), his widely cited study of Atlanta, political scientist Clarence Stone described an urban regime as "the informal arrangements by which public bodies and private interests function together in order to be able to make and carry out governing decisions" (p. 6). Specifically, he argued that urban regimes were groups of actors who often harbored very different interests, but who had access to key resources and came together (cooperated) purposively, to accomplish some task. Central to his thesis was the acknowledgment that cooperation could not be automatically assumed, and that it was more likely to occur in certain circumstances than in others. By focusing on the question of how things get done (as opposed to who holds the power, and "over" whom), Stone shifted the analytical lens to what he described as "power to," a "social production model" that emphasized the capacity to act, as opposed to the state of domination (Stone, 1989; Stone, 1993; Stone, 2006).

While regime theory recognizes that "power over" and "power to" are intertwined (Stone, 2006), critics argue that it places too much emphasis on "power to," or collective power, and ignores the extent to which "power over," or distributive power, fundamentally shapes and directs the former (Gendron, 2006; Gendron and Domhoff, 2009). ${ }^{2}$ Furthermore, regime theory's assertion that the preferences of different groups are not 
fixed, but rather can develop and change in the process of collaboration with others (Stone, 1993), has been challenged by scholars who maintain that this claim highlights important theoretical deficiencies, namely the lack of "a substantive grounding in the commodified nature of land in the United States and a larger historical context about why local governments are weak" (Domhoff, 2006).

In contrast, Gendron and Domhoff (2009) contend, because growth machine theory places the conflict between a growth coalition's pursuit of "exchange values" and a neighborhood's defense of "use values" at the very center of its framework (Logan and Molotch, 2007), it provides the most useful lens for understanding urban power structures and politics. Nevertheless, based on their case study of Santa Cruz, the authors conclude that the growth machine thesis does have certain limitations, among them its shallow treatment of conflicts and tensions in the urban growth machine itself: “... even though growth coalition theory recognizes that there can be disagreements and divisions within the growth coalition, it tends to argue that these differences typically involve disputes over where new developments will be sited within a given locale. Such disputes are usually portrayed as relatively minor matters compared to the broad consensus within the growth coalition on the fact that all its members benefit from growth..." (Gendron and Domhoff, 2009 p. 203-4).

Several studies engaging a comparative political economy perspective offer a more nuanced take on the inner workings of growth machines, highlighting the extent to which pro-growth coalitions operate differently, and with varying degrees of effectiveness, in different social, economic, and political contexts. Drawing on their examination of ten cities (including representatives from the United States, Canada, the United Kingdom, France, and Italy), Savitch and Kantor (2002) conclude that "... urban development has more to do with nuance than with a simple set of choices about whether or not to develop" (p. 51). The tendency to focus on whether "growth machine" or "anti-growth machine" agendas dominate in urban politics, they argue, is reflective of the American origins of the term, and ultimately oversimplifies a very complex reality. Similarly, DiGaetano and Klemanski (1999) highlight the failure of existing theories of pro-growth politics to explain urban development in the United Kingdom: “... growth machines, a privileged position for business elites, and privatism simply have not been constituting features of postindustrial urban politics in the United Kingdom" (p. 251-2). Horak's (2007) study of post-communist preservation and development in Prague's historic core likewise demonstrates the degree to which unique political circumstances can determine the way urban growth occurs. Finally, noting the dearth of research on the factors influencing the actions of developers, Fainstein (2001) calls for increased attention to how these local actors make decisions. Based on her extensive case studies of New York and London, she argues that "the development industry constructs and perceives opportunity through the beliefs and actions of its leaders operating under conditions of uncertainty.... They do not merely react to an objective situation but operate within a subjective environment partly of their own creation" (p. 25).

While Fainstein acknowledges that New York and London are "special" cases, and thus not representative of how urban development occurs in all or even most cities, the importance of her emphasis on understanding the subjective perspectives of local private actors cannot be overstated. Indeed, as I demonstrate below, real estate practitioners, whose role is to find and develop appropriate locations for companies, harbor definite views about what the development process in urban areas is like-views which do not 
always comport neatly with existing theories of the politics of urban growth. To the extent that these perceptions influence how business actors assess potential sites, interact with municipal officials, and ultimately make location decisions, they have obvious theoretical and practical implications.

\section{METHODS}

Between November 2005 and March 2006, I conducted a series of in-depth interviews with 30 real estate professionals. ${ }^{3}$ Half of the interviewees $(n=15)$ were members of a national trade organization comprising commercial real estate brokers, developers, industrial location specialists, and other individuals whose companies drive and support the commercial real estate process. These respondents are referred to hereafter as "Service Providers." The other half $(n=15)$ were members of a national trade association composed primarily of corporate real estate professionals-i.e., the "end users" of the real estate process, who typically run the real estate and related support functions for companies whose primary business is not real estate. These respondents are referred to hereafter as "End Users."

Service Providers are professionals commonly hired by firms to assist in the location or relocation process. Commercial real estate brokers, for instance, typically handle the negotiation and closing of commercial and industrial transactions, land sales, and leasing deals. Developers are responsible for identifying commercial development opportunities, acquiring land or existing sites for development, and overseeing construction. End Users perform real estate-related functions within corporations. They are predominantly senior-level employees who have a significant voice in location decisions.

I deliberately included equal numbers of each group in the interview sample to allow for a future study of the potential differences between the populations. The present study, however, is not concerned with comparing the views of Service Providers and End Users. For the purposes of this analysis, the 30 respondents are treated as one sample. In the description below, the characteristics of Service Providers and End Users are presented separately simply because the distinct jobs held by the members of each group necessitated the collection of slightly different data (e.g., whereas End Users are involved in the location decisions for a single company, Service Providers are involved in the location decisions for a variety of companies, often in different industries and locations).

The respondents represented a wide range of geographic locations and industry types. Service Providers generally concentrate on projects in a particular region of the United States. Of the 15 Service Providers interviewed for this project, five operate mainly in the Northeast, five in the Central states, three in the Middle-South Atlantic, and two in the Pacific states. The sample was an experienced group, with all but one of the interviewees holding a minimum of ten years of experience in the real estate profession. (In fact, the majority had been working in real estate for at least twenty years.) Most respondents serviced clients in diverse industries, and had experience with several different types of development projects. When asked to identify the type(s) of development projects that constituted most of their business, nine indicated corporate or office buildings, eight said industrial buildings or manufacturing plants, three said mixed-use projects, and two said retail establishments. ${ }^{4}$ 
Nearly all of the End Users worked for large, national corporations that have multiple facilities in the United States. All but one worked for companies with at least 5,000 employees, and the majority worked for companies with at least 20,000 employees. This is not surprising given that smaller firms, for whom opening or relocating a facility is a relatively rare event, typically lack the need or the resources for a permanent in-house real estate function. Of the 15 End Users interviewed for this project, eleven worked for companies that had at least 100 properties or facilities in their portfolios, two worked for companies that had between 50 and 100 properties, and two worked for companies with fewer than 50 properties.

The companies that employed the End Users represented a diverse group of industries: three were in finance/insurance, three in retail, and three in consumer products; two were in manufacturing and two in distribution/logistics; and one each was in healthcare and information technology. Like the Service Providers, the End Users interviewed for this study were quite experienced. Twelve had a minimum of ten years of experience in real estate, and the remaining three had at least five years of experience each. Sample characteristics are summarized in Table $1 .{ }^{5}$

In keeping with the accepted practice for this type of qualitative research, I employed a flexible approach to each interview, treating it more like a "guided conversation" as opposed to a fixed set of questions (Lofland and Lofland, 1995). Thus, while the interview guide included a number of closed questions designed to elicit specific information about the respondent and his/her employer (e.g., How many properties are in your company's portfolio? How long have you been working in the real estate industry?), it also featured open-ended probes intended to explore how respondents think about the development process in urban areas (e.g., How does the development process in a given municipality factor into the firm's location decision? When comparing the development process in [city] versus the surrounding suburbs, how would you describe the differences?). At the end of each interview, I left time for unstructured dialogue with the respondent, which I prompted by asking whether there were any other important aspects of the location decision process that we had not yet discussed. Interviews ranged in duration from 45 to 90 minutes, with a median length of approximately 60 minutes. ${ }^{6}$

Because this research was designed to be exploratory, the themes discussed in the next section were generated inductively during the data analysis. Thus, I did not have the opportunity to ask all respondents to comment directly on each. Given that, it is not possible to determine the precise number of respondents who would agree that each of the issues identified presents a challenge in the development process, nor can I rank the characteristics in terms of their perceived significance. Future research might endeavor to measure the relative importance of these issues by subjecting them to a direct test via a survey or structured interview.

\section{INSIDE THE GROWTH MACHINE}

Most development decisions are the result of a complex process that involves identifying, evaluating, and comparing a range of factors for multiple potential locations. The process is complex, in large part, because it involves a substantial number of actors. To be sure, while every respondent talked about the need for accurate financial models and other quantitative data to determine whether a deal would be viable, they all emphasized 
Table 1. Sample Characteristics

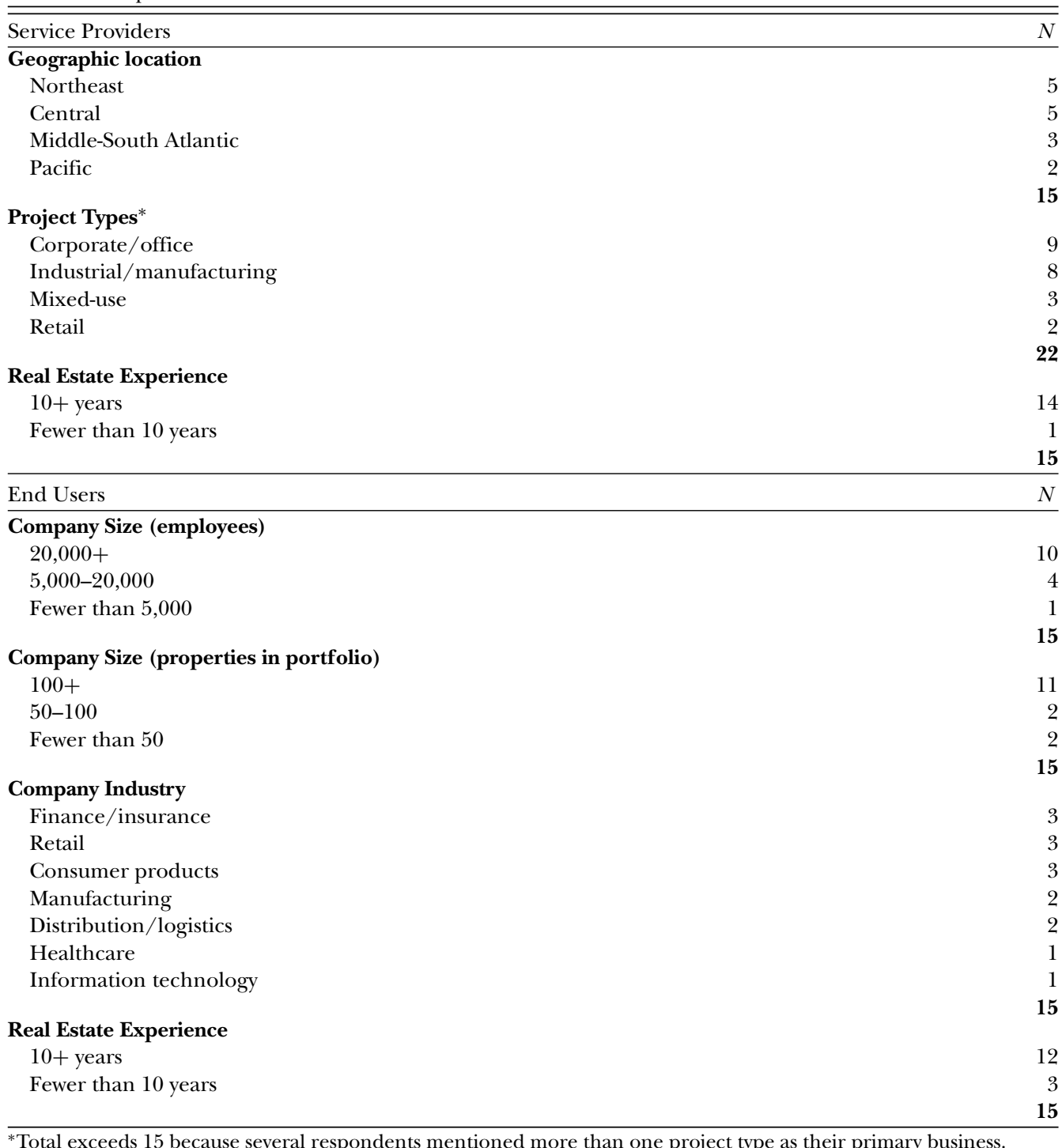

*Total exceeds 15 because several respondents mentioned more than one project type as their primary business.

that success or failure was largely dictated by the extent to which they could navigate relationships with key actors, and recognize the interests that each had in the development process.

Given the range of projects that might fit under the heading of urban development, it would be extremely difficult to state with any degree of precision who the central players in "the development process" are. While some companies may hire an outside location consultant to help determine the appropriate place to site their operations, many large firms keep internal staff (like the End-Users interviewed here) on the payroll to perform this function on a regular basis. Many municipalities employ economic development 
professionals; in others, elected officials handle issues related to economic development. Some minor projects (e.g., locating a small office facility) may be executed by a relatively small number of company employees and local permitting officials. Others-for instance, redevelopment of hazardous brownfield sites, multi-million dollar development efforts eligible for substantial financial incentives, projects that involve the use of eminent domain-may well require legions of actors, both private (e.g., consultants, developers, architects, lawyers, public relations executives, environmental specialists, etc.), and public (e.g., government officials at the local, state, regional, and even federal level).

Nevertheless, the image of a "machine" suggests to us that, whoever the actors are, they operate together in a smooth, coordinated fashion. ${ }^{7}$ Yet, the real estate professionals I interviewed tend to see the process of getting a site up and running in an urban area (i.e., shepherding a company through permitting, approvals, appeals, etc.) as largely fraught with challenges and obstacles. Specifically, the data reveal several ways in which real estate professionals see their capacity to act as constrained or limited. Below, I describe four perceived checks on the power of these practitioners: (1) the (re)-election interests of politicians; (2) the professional interests of economic development staff; (3) bureaucratic procedures and zoning regulations; and (4) mobilized community members and groups.

\section{RE-ELECTION INTERESTS OF POLITICIANS}

Cities are, by their very nature, complicated political creatures. Since individual states determine how municipalities are created and governed, the nearly 20,000 local governments in this country vary greatly in the ways they dole out power and authority among officials. While the majority of municipalities are ruled by some form of council-manager or mayor-council government, in practice, they end up looking and acting quite different from one another. What is nearly universally true, however, is that municipalities are run, at least in part, by people who are elected to their positions (National League of Cities, 2009). This fact has very real implications for the way in which the economic development process unfolds in many municipalities. Elected officials need to carefully balance their stated philosophies and positions on the key issues with the need to be responsive to their constituents:

[City] is a good example. The city council is reasonably pro-business, pro-growth. You can talk to them; they get it. But the community put on the ballot in November a no-growth initiative. Buildings could be two stories, maximum, throughout the city. It got defeated, but let's just say it left their city council a little gun-shy. So I mean, you can talk to those council members, but when your project comes up for a vote, and there are 50 people in the audience throwing wadded-up paper things at them not to vote, you will find that their number one priority is getting re-elected. And being pro-business is a distant second that they no longer remember.

When residents object to a proposed development project, the complaints are often heard loud and clear by their elected officials. This is with good reason-elected officials recognize that the very people who brought them into office can take them out again: 
Politics being politics, if a contentious project is brought to the council members' attention, and it touches a nerve at a political level-for instance, if it's an election year and they want to pander to the constituents or whatever, the city council can find a way to get involved or slow down a process if they think that's what people want. I happen to be involved in a project in [City] that's in that situation ... we're trying to represent our side of the story as fairly as the opposition is unfairly presenting it to the council members. It's a fun process, let me tell you ... and this is a project that wouldn't typically even require city council's vote or opinion, but they've gotten involved.

This respondent's choice of words—“touches a nerve," "pander"-reveals a frustration with, even blatant condescension toward, the political aspects of the development process that the typical reader may find deserving of little sympathy. Indeed, the point here is not to suggest that private investors are merely the hapless victims of politicians' calculated campaign strategies. Rather, it is to understand the development process from the point of view of the people engaged in it.

Many real estate professionals describe "reactive" local governments that throw economic development initiatives off course. Respondents spoke of city councils actively and persistently wooing companies to their borders, only to reverse course late in the game after sensing discontent among their constituents. Others recalled mayors and council members, previously uninvolved in the development process, whose sudden passionate fight against a project smacked of an attempt to "curry favor" with select voters. Again, these stories in no way discount or undermine previous research that has documented numerous examples of unwanted development (e.g., wastewater treatment facilities, power plants, prisons) popping up in places where residents either lacked the voice or process to oppose them, or were represented by officials who simply chose to ignore their concerns (see, e.g., Bullard, 2000; Cole and Foster, 2000; Pulido, 2000; Faber and Krieg, 2005). Clearly, both outcomes-elected officials siding with private investors at the expense of residents, and elected officials reneging on development deals when the political terrain seems too risky-can and do occur. From the vantage point of real estate professionals, however, the self-preservation instincts of local political figures represent a significant challenge in the development process.

The influence of politics is evident not merely in the behavior of individual government officials around election season. It becomes institutionalized in the formal rules and regulations that govern the process by which companies can establish operations in a given location:

All of these things [zoning regulations] are creatures of politics, because the people who put them in place are political creatures. Yeah, nominally, you have a planning staff, but at the end of the day it's all politics. It's all people trying to get elected. It's about self-preservation of the elected people and also the appointed people who depend on the elected people for their jobs. [City] zoning is set up deliberately to have as few as possible clear-cut "yes" and "no" answers.... And the reason is that the political people pander to what they call the neighborhoods, which is basically interest groups, self-appointed interest groups.... It forces any project that is potentially controversial and therefore bad for the elected people and their appointees to have to go back through this massaging process with the interest groups. And what 
that does is defuse the possibility that there's going to be political consequences from that stuff. That's what it [zoning guide] is designed for. It's not designed to attract and retain. It's designed for political preservation. It has nothing to do with economic development.

When regulations are straightforward, yes or no, meet-these-requirements-and-you-canbuild affairs, local officials lose some degree of control over the development process. If residents object to a proposed project, and the municipality's zoning guidelines do not allow for some wiggle room in their interpretation, it becomes more difficult for officials to retard or block the project's progress. In other words, it is harder for elected officials to take action in response to their constituents' protests.

For that reason, many cities have been reluctant to implement "by right" zoning or development, which allows property owners to reuse existing buildings on their property without the need for an additional review or public hearing, provided the new use is consistent with the zoning for that space. Not surprisingly, by right development is quite popular with the real estate community, in that it reduces some of the uncertainty that surrounds the development process by eliminating the possibility that a project can get hung up by appeals or delayed approvals. In contrast, many municipalities build a certain degree of uncertainty into the process by, in essence, putting an asterisk in the regulations book:

Zoning can drive a lot of unpredictability. In some places like [City], it's pretty cut and dried. It's either yes or no. You can do it or you can't. But then you go to some places where it's all SP, which means 'needs a special permit'. Well, in some communities, that's shorthand for 'let's make a deal'. So then I have to figure out how long it will take me to find out what kind of deal they're willing to make, and then I have to figure out if that will work for me. Which gets to this idea of uncertainty that we've been talking about.... If you look at [Other City], you'd see that there's a lot of stuff that requires a special permit, that's not a clear yes or no. And if it is a yes, the steps that they make you go through to get the yes could have their own uncertainty built in as well. So you have to meet with the following boards or groups, and there's some sausage that's going to get made as you go through that process, and you don't know whether what you'll have at the end will be something that you really want to eat.

PROFESSIONAL INTERESTS OF ECONOMIC DEVELOPMENT STAFF

In many cities, however, elected officials are not the only, or even the primary, individuals overseeing the development process. Economic development professionals are frequently hired to formulate and execute strategic plans to guide a municipality's evolution. These staff members typically have experience working with companies and real estate providers which they can draw on to clarify and streamline the development process. As hired employees, they are also less likely to be beholden to specific resident groups, given that they do not need to count on their votes (at least directly) to keep their jobs. This does not mean, however, that they are completely immune to outside influences. Indeed, 
many development professionals achieve their positions on the basis of what they promise to do for the city:

We had a building in one community and the economic development official came in and decided that he wanted it to be the region's high tech corridor. And he was going to get the community a helipad and they were going to attract high tech. And that's how he got his job. He sold the city council and everybody on that. Well, here I am sitting with a vacant industrial building and I'm trying to lease it to an industrial company. And yet, I'm trying to keep this guy at bay, to not let him meet with the prospective tenant because they're trying to figure out 'Is this community going to be friendly to us? Will I have the labor I need? Do they want us here?' And I've got this guy running around saying 'We don't want your jobs here. We don't want you here. '... And now, of course, the planner is no longer around because none of it panned out. He sold the community on a big idea that they liked, and sure, it sounded great. But what he was selling exists in Boston and San Jose and maybe a small part of Atlanta, but it wasn't right for that community.

From the perspective of real estate professionals, municipal staff members frequently use their positions as a means to exert authority, sometimes at the expense of what may be in the best interests of the city. In this we see echoes of Weber's $(1922,1978)$ cautionary tale about the potential for bureaucrats to assume too much power in society, tightening the "iron cage" of rule-based control:

We had our first meeting with all the permitting and planning people in [City] and there were 35 people at this meeting. And we went around the room and each of the staff members stood up and said what we had to do to get through their process.... And after about the $10^{\text {th }}$ person, this city council person, a lay woman who doesn't really know much about development per se, stood up and said, 'I'm just here to tell you ... these people are coming here to build a $\$ 150$ million showcase property for one of our great corporations, and you know, if I were them, I would be offended. Every one of you all are running around barking orders at them. There ought to be someone in here that makes this a good process for these people. It's complicated enough what they've got to do.' I mean, there are some communities that get it and they're friendly and they work with you throughout the process, and others that don't. Communities like this, where the bureaucrats don't give a darn, well, you sometimes need the elected officials to push them to care.

As this last excerpt suggests, one of the most vexing challenges real estate professionals may face is a disjuncture between the words and deeds of elected officials and those of the municipality's bureaucrats. Respondents spoke of needing to simultaneously navigate (at least) two parallel development processes marked by mixed messages and contradictory requirements - the one championed by the government officials, and the one set forth by the economic development staff. As one respondent put it:

When I see that the mayor and the city council and the planning staff are not on the same page, it makes me want to turn around and leave the room. There needs 
to be a master plan, and municipal officials need to be in agreement and working together. Otherwise, how do I know that I am going to make it?

In contrast to the well-oiled, finely tuned operations implied in the image of a growth machine, real estate professionals frequently encounter fragmentation and dissent among the individuals and groups responsible for a city's economic development. This often occurs when the strategies devised by the economic development staffregarding, for instance, which specific companies or industries to try to attract to the municipality-run counter to those advocated publicly by the mayor or city council members. Several respondents described investing significant resources in the pursuit of a development project that appeared to fit a city's profile (and that the elected officials had supported) only to have it quashed later by staff in the city's economic development office, who explained that the project did not fit with their strategic vision. Whether these conflicting interests represent political power plays among elected and hired leaders, or genuine disagreements over the appropriate economic development strategy for a municipality is largely irrelevant to real estate professionals when the end result-i.e., a prolonged, postponed, or terminated development project-is the same.

BUREAUCRATIC PROCEDURES AND ZONING REGULATIONS

Even when all of a municipality's leaders are on the same page, the complexity that characterizes most development processes can make them challenging for even a seasoned professional to navigate. The sheer number and variety of municipal activities involved often necessitate that the economic development process be highly compartmentalized. Indeed, getting a company up and running in the city typically requires permits from the fire department, the health department, the building department, the conservation/historical preservation department, the water and sewer department, the traffic department, and so on. While a few respondents spoke of specific municipalities that had coordinated and streamlined the various steps in the process, most described city departments that operate in autonomous silos, establishing timelines and standards for permits largely independently from the other bodies in the process. As one real estate professional explained:

It's so important to have a clear, understandable process ... I mean, I never expect that a single staff person will have the answers to all of my questions, but there's got to be a way for me to find out what I need to know, who I need to go to, and when. When are the staff committee meetings? When are the planning committee meetings? When does the city council meet? When does the variance board meet?... In some of these cities, I sometimes feel like I'm sucked into this process that's totally discretionary, totally subjective, and I have no idea if I'm ever going to come out on the other end with a project. We have a phrase here that we always laugh about because one of my coworkers uses it all the time: "certainty of outcome". Are you going to get there? It always amazes me when I call a staff planning person and I ask them what they think the reaction of the planning committee is going to be, and they say, "I have no idea." How can you have no idea? You work with them-at least, 
you should work with them. It feels like they're telling me, "Well, submit your plans and take your chances." And that's really disheartening.

Unless a company is, for instance, simply leasing office space in an existing building, a certain level of complexity seems unavoidable when establishing commercial properties. But when the steps of the development process are spread out into the hands of many distinct decision-makers, and not governed by an overarching system operating on a shared schedule, the complexity can become daunting, if not altogether unmanageable. It is worth noting, of course, that even the most challenging development processes will not discourage some real estate professionals from pursuing a desired location, as this respondent described:

I think there's a size at which a company will suffer through the bureaucracy. Take a [Fortune 500 Company], for example, or someone like that. They are big enough and have enough money that they can hire architects and engineers and other specialists who know the ins and outs of the process, who know what needs to get done, and who to talk to to get it done. They'll be able to make their way through it. But if you are a smaller company, or if you're a company that's just starting out in an area and is not familiar with it, I really don't think [City] would be a good choice for you.

With enough money and manpower, a large corporation can often maneuver its way through a complicated development process if it truly wants to be in that location. Smaller companies that cannot afford to hire a team of professional experts to guide them through the process may be more easily deterred. Similarly, companies seeking to move to an entirely unfamiliar area often lack the local knowledge and contacts needed to understand some cities' requirements.

Local knowledge can be particularly important given that municipalities across the United States have dramatically different industrial and commercial histories. Specifically, the industrial legacies of many cities have left them with a patchwork of regulations and processes that evolved over the years, typically by virtue of isolated, piecemeal changes in response to specific circumstances at specific times. As a consequence, the current zoning regulations and permitting processes that many cities have in place now often lack an overall cohesive logic; they are in some cases anachronistic or contradictory, and thus can be difficult to navigate:

One of the things that is problematic in New England is you have these cities that have created all of these boards over the years ... and they have a lot of power. I dealt with a city once where the water board was literally these 3 guys who met in somebody's garage every other week. But they have been entrenched in the system forever.... It's just not obvious to me how you are supposed to work with them within the system, but you've got to figure it out because they have a lot of power.

Back in the 1970s, there was a group of citizens in [City] that did not want [Institution] to expand from its current location across the street. So they negotiated an agreement to prevent any development on the other side of the street. Now here 
you are 30 years later and all of the development is piling up on one side of the street, because of one project back then that some people did not want to happen. It's ridiculous.

As the above quotes suggest, cities with a long record of commercial development often have a history of actions and reactions related to that development that, taken in aggregate, appear to private investors to be illogical. The end product is a process that feels very bureaucratic, or as one developer described it, "arbitrary." Most cities typically do not have the luxury, political will, or desire to clear the slate and craft a new set of policies and regulations; rather, they tend to amend and add on to existing regulations. As he described his frustration with the development process, one respondent I interviewed in his office stopped mid-sentence, walked into another room, and brought back a pile of documents. These, he told me, were the zoning regulations for three local municipalities. One was a slim volume, similar to a pamphlet or a brochure. Another was a fairly thick set of pages in a three-ring binder, and the third was an extremely heavy, overstuffed binder (more like a textbook, in fact) that he dropped on the conference table with an emphatic thud. He bemoaned the complexity of the two larger binders, and explained what he saw as the "pathology" of regulations in many cities:

Zoning regulations fall victim to inertia. Once you have this [big binder], you never get down to this [small binder]. It's gotten bigger over the years and will just keep getting bigger. It won't go in the other direction. These guys [small binder] will, over time, gradually add regulations and appendices and exceptions and eventually get up to [big binder], but you never get more simple it seems.

Many other respondents echoed the concerns of this practitioner, arguing that bureaucratic hurdles act as constraints on growth not only by making the development process confusing for firms, but also by slowing it down substantially. In the early $20^{\text {th }}$ century, when most firms were essentially a collection of physical assets established and maintained in one location throughout the life of the business, start-up times were not particularly important. In the post-industrial world, however, firms can and do move around frequently. Thus, "time to market" is critical. Outdated or inconsistent procedures and regulations that impede the development process for firms are perceived by many real estate professionals as a strong disincentive to local growth. In many ways, of course, this is the point of municipal permitting processes and zoning regulations: to ensure that development only occurs within certain physical parameters and to serve carefully specified functions-i.e., to put some controls on growth. The bigger issue for real estate professionals, then, is not the mere existence of regulations and procedures, but rather the confusion and ambiguity that may result from their proliferation, as Robert Merton (1957) describes in his discussion of the dysfunctions of bureaucracies. ${ }^{8}$

\section{MOBILIZED COMMUNITY MEMBERS AND GROUPS}

While there is a substantial body of literature that documents tensions between private elites and local residents over contested land, and community-led resistance efforts (some successful, some not), these findings shed light on how real estate professionals think about 
community involvement in the development process. Whenever exploring the viability of a development project, practitioners explained, they have to take into account the concerns of residents. Certainly, in some cases (and probably more than my respondents were willing to acknowledge) any attention to the public's interests is fueled solely by necessity-i.e., they either need to secure the explicit approval of residents or their elected representatives in order to proceed, or they recognize that they will have to find a way to manage, quell, or circumvent public opposition. Others claimed that they had learned over the years that it was simply prudent business practice to establish a reputation as a good institutional citizen and community-minded neighbor. Whatever the motivating factor, rarely is public opinion excluded entirely from the decision-making process.

Respondents did, however, articulate two different ways in which mobilized public interests can serve as a constraint on business development. The first concerns disagreements among various community members and groups as to the type or amount of economic development that is appropriate for their city. The second focuses on the actions of single individuals or households who, assisted by provisions in local appeals processes, are able to advocate for their preferences and forestall or prevent development.

The socioeconomic, racial/ethnic, and lifestyle heterogeneity that is common to many cities can be a double-edged sword when it comes to the location of commercial activity. On the one hand, the diverse populations found in many cities can be a boon to firms, as they offer a wide range of human capital skills from which to draw potential employees, and an equally broad array of customer demands to which niche businesses can stake a claim. On the other hand, this same diversity can pose problems for firms that are considering urban development, because it can undermine the notion of a "common identity" or shared sense of purpose among residents.

The various demographic and consumption profiles of urban residents often translate into a lack of a unified vision concerning the type or amount of economic development that is desirable: Boutique stores or low-cost retailers? Office space or industrial? Build anew or preserve? Biotech or traditional manufacturing? Indeed, by their very nature, many urban areas are home to numerous small interest groups that disagree on the type of investment that is "right" for their city. For the private investor attempting to determine whether a given location is a viable option, all of these competing voices can lead to confusion and uncertainty:

The challenge that we are facing with this project is that the opposition that we are getting is coming from all different levels. The complaints different people have are so diametrically opposed-this project calls for too much parking, it doesn't provide enough parking. Some like that it will bring in a lot of jobs, others think they aren't the right jobs. Some people want a denser development, others want more open space. So we just sit back and let them vent. But it certainly makes it impossible to try and come up with a proposal that will meet all of the criteria.... I think that the closer people are to each other, the more they are falling all over each other, the more tension there is, the more they are going to want to have their opinions heard.... I think density has a big impact on the need for different neighborhoods to feel represented in the process, to feel like they're not getting lost in the big machine. 
As this respondent highlighted, the lack of a general consensus among a municipality's residents presents significant challenges. Real estate professionals expect to tailor proposals and project plans to meet established zoning guidelines and other requirements laid out by the city. But given that residents typically wield some say in the process as well, either by the formal right to approve or appeal a project or via their informal influence on municipal decision-makers, practitioners must also make sure that they attempt to respond to their concerns as well. When there is no clear agreement on what the top issues are, or if different groups present opposing opinions that cannot be reconciled, practitioners will question whether they will ultimately be able to win approval for their project.

Several respondents pointed to what they perceived as the "unpredictable" behavior of city officials as evidence that a diversity of public opinion can make it difficult for municipalities to design and execute a consistent, coherent economic development plan:

Consistency of philosophy is a critical thing in my opinion. If I find a city that has displayed a consistent philosophy about who they are and what's important to them, then I'm much more likely to take a risk with them in the future than if I look at a city council's voting pattern and it's all over the place, and it's clear that they are just putting out fires, being reactive to whatever it is that the community group du jour complained about. That lack of a consistent philosophy is a real big problem.

In fact, much of the red tape that emerges in large urban areas can be interpreted as a means of protecting the interests of individual "micro-units" (e.g., neighborhood blocks) by giving them some authority over the development process. New York City's numerous community boards, for instance, can wield considerable influence in the development decisions that affect their small slice of the city, despite the fact that their recommendations are not binding (Pecorella, 1994). ${ }^{9}$ While micromanagement of the process at this level may help to keep the peace between neighboring groups by providing residents with a certain amount of control over what happens within the confines of their area, it may also undermine the larger economic agenda embraced by the city. As one real estate professional put it:

All of a sudden when [Mayor] came into office, the civic associations transformed from being a place where residents could go to vent, to being the place where businesses actually had to go to get the approval. You had the same angry people in the room, but now these people had power, and the city paid a lot of attention to them. To the point where people would stand up in meetings and say 'We can stop this [development]. We can keep this from happening.' And I'd say, 'Why? Why do you want to stop it? Is it going to cause a problem?' And it seemed like the response was, 'Well, because we can.' And it felt like they were flexing their muscles just to flex their muscles.

Perhaps even more importantly, however, the experiences related by these practitioners call into question the notion of a collective community voice, united in its opposition to growth and motivated by a steadfast desire to protect use values. Indeed, respondents described some development projects that enjoyed broad community support, but which faced challenges from lone residents or households. In what could be termed the "one 
and done" phenomenon, growth was forestalled, either temporarily or indefinitely, not by mass opposition, but rather by the actions of selected individuals:

I think the way to think about it is, the more people that are near the area you're building, the more chance you've got of being appealed. For example, in [City], just to get a special permit you have to go through a process where no one appeals. One appeal and you're dead.

One thing that really makes our business very difficult is the fact that for $\$ 50$, somebody, anybody, any abutter can tie you up for 2 years.... We have a property right now that is almost fully permitted and we have a couple down the street that has appealed us. That's ok. But they don't want to talk to us. Their attorney won't let us talk to them.... Now that could kill this project. This is a 400,000 square foot project that is going to send approximately $\$ 1$ million in tax revenue into this community and this couple could kill the project if we don't find some way to address it.

We've got a project where we're under appeal. There's an existing supermarket that is way too small for the market. It's a dump. It needs to be enhanced. The neighborhood is completely in support of a new supermarket. They have been great. But two people who own houses right next to the center are appealing us until we buy their houses for an above-market price. And I'm not talking about $5 \%$ above market, ok? So we've got to go through the appeals process and figure out whether we can get the appeal dismissed because there's no basis for it ... and that could take years. So even though we got tremendous feedback from the community on this project, that it was the right thing to do, and it was supported, it only takes one person to derail it.

These professionals, like others who discussed their concerns about resident appeals, drew distinctions between widespread community concern about a proposal, and what they saw as the ability of a "rogue" individual or group of individuals to hijack an otherwise popular project. The former, respondents agreed, is something to be expected, planned for, discussed, and addressed as part of the normal development process. The task of gauging the temperature of the community, hopefully with the assistance of municipal officials who have a handle on residents' preferences and fears, is seen as a standard part of doing business. What is more daunting to real estate interests, in many respects, are the unexpected appeals from one or two independent parties. Because they are often unforeseen by either the practitioners or the city leaders, there is no opportunity to ferret out issues in advance and attempt to tweak the proposal in response. As a consequence, significant time and money is sunk into a project that may never make it to the finish line.

\section{DISCUSSION}

While not invoking the language of urban political theory, the real estate professionals interviewed for this study effectively voiced challenges to the notion of the urban growth machine. They see the exercise of power at the local level to be less coordinated, 
consensus-driven, and growth-oriented than the growth machine thesis suggests. These data thus provide additional evidence for the existence of widespread tensions in the growth machine (Molotch and Logan, 1984; Molotch, 1988; Jonas and Wilson, 1999). In particular, real estate practitioners perceive their own capacity to develop commercial properties to be constrained not only by municipal regulations and bureaucratic procedures, but also by the interests and actions of multiple actors: elected officials, professional staff, and community members, any of whom may-or may not-support specific growth efforts. In other words, real estate professionals conceive of the political environment in which local development occurs in far more "pluralist" terms than that asserted by prevailing theories of the urban power landscape.

Consistent with the work of Fainstein (2001) and Elkins (1995), this research therefore emphasizes the need to examine the subjective perceptions of private sector actors in order to fully appreciate the complexity and dynamics of urban growth. By illuminating how one segment of the growth machine-real estate professionals-views the development process, this research makes an important contribution to the literature on urban power. The findings illustrate that real estate professionals think about the development process, and articulate their role in it, largely in terms of a "social production model," or "power to" (Stone, 1989). The language of the respondents is striking in its emphasis on a desire to get things done and accomplish objectives in the context of disparate preferences brought to the table by various groups. Negotiation and compromise with other actors-regardless of their position in the social structure (e.g., residents, elected officials) - are typically seen as acceptable strategies, if not desirable ones, provided they ultimately increase the likelihood of achieving stated goals (Stone, 1993; Stone, 2006).

Perhaps most importantly, the views expressed by the real estate professionals call into question the amount of power-both absolute and relative-typically ascribed to them by existing theories of urban development (Elkin, 1985; Stone, 1989; Logan and Molotch, 2007), revealing instead an understanding of the power structure that is decidedly pluralist in nature. Respondents tend to perceive other actors in the urban landscape-elected officials, municipal planners, community groups-as more powerful than themselves (or, at a minimum, equally so). Repeated references to uncertainty and unpredictability reflect an ongoing concern that development efforts can be derailed by any number of individuals, groups, or processes. Furthermore, to the extent that some municipalities have institutionalized mechanisms by which individual residents can stall or prevent development by registering an appeal (as some respondents described), this highlights an interesting inversion of the typical hierarchy in which exchange values trump use values (Logan and Molotch, 2007).

One does not need to agree with the views revealed here, or even accept them as valid or justifiable, to acknowledge that it is important to understand them. If real estate professionals believe-rightly or wrongly - that their power is limited in ways that they find problematic, they will likely take actions designed to circumvent those constraints or reduce their impact. For instance, previous work demonstrates that given a need to ensure that expensive and time-consuming real estate deals make it to the finish line, practitioners will strive to reduce uncertainty in the development process, even if doing so may change where a firm ultimately decides to locate (Kimelberg, 2010).

Of course, perceptions of power are not the same thing as actual power. While the data presented here reveal what real estate professionals see as the challenges of urban development, they do not indicate whether (or when) these challenges are sufficient enough 
to either deter or prevent private investment. This study did not provide an empirical test of the conditions under which decision makers are willing or able to contend with the challenges associated with urban development (e.g., Schneider and Teske, 1993; Warner and Molotch, 1995), versus opting for less complicated or contentious alternatives. Thus, future research ought to probe the relationship between what real estate professionals believe about the limits on their power and the reality of what they are actually able to accomplish. If, for instance, it turns out that business actors typically manage to overcome these perceived obstacles and succeed in pushing their development initiatives through, then this would perhaps serve as even stronger evidence of the power of the private sector in urban politics.

Indeed, examining whether real estate professionals' perceptions of constraint predict failure-or, alternatively, are merely grumbles about nuisances and speedbumps encountered in otherwise successful ventures-gets to the heart of the debate about the relationship between distributive and collective power, or "power over" versus "power to" (Gendron, 2006; Stone, 2006; Gendron and Domhoff, 2009). If collective power can only be exercised effectively after questions about distributive power (or who has power over whom) have been resolved (Gendron and Domhoff, 2009, p.195), then development victories achieved in spite of reported constraints may be interpreted as support for the primacy of "power over," in that growth coalitions "... exert power constantly ... [in order to] maintain their dominant position" (Gendron and Domhoff, 2009, p. 203).

Clearly, these data represent only one side of a much larger, more complex story. Absent from the present discussion is an analysis of how other actors in the development process-in particular, municipal officials and residents-perceive and respond to the issues and situations described by real estate professionals. At a minimum, the findings presented here indicate that we should not assume, a priori, that community groups are necessarily anti-growth, or that municipal officials are necessarily pro-growth. For example, subgroups within the broader community can, and often do, disagree with each other on the desirability and appropriateness of specific development projects. To the extent that the views of residents and public officials echo the fragmentation depicted by real estate professionals, this would further support a pluralist conception of local power structures. It would be especially instructive in this regard to not only examine the views of these discrete actors in isolation, but also consider how they are interrelated, and the degree to which their views on urban political power are a function of their positions in various structural relationships.

Likewise, additional research could benefit by building on the research design utilized here to explore regional variations in the form or capacity of urban growth machines. Indeed, in his discussion of potential constraints on the activities of local growth elites, Molotch (1988) points to the role that certain geographic or physical factors may play in aiding or hindering the execution of growth agendas. The data collected for this study are based on interviews with real estate professionals working across the United States, and thus offer some initial hints that the power of the private sector may be more limited, and private-public elite relationships more at odds in certain parts of the United States than in others. Specifically, the data suggest that real estate professionals may experience greater challenges to their capacity to act in older industrial cities of the Northeast (where respondents reported local power structures that are more fragmented and firmly entrenched, and bureaucratic procedures that are more complex) than in the newer cities of the South and West. While the interviews were not designed to elicit the detailed 
information needed to support a rigorous test of the extent to which variations in natural or built environment, industrial history, administrative form, or local and/or state fiscal policies might affect practitioners' perceptions of their power, future efforts should endeavor to tease out these relationships. In particular, looking across cities in the United States, and not merely at the power arrangements in single municipalities (the case study approach often favored in this area of research), would do much to further this agenda.

Finally, since these data focus on real estate professionals working in the United States, it is important to consider them in light of recent comparative analyses that recognize the influence of subjective actor perceptions on the way that development unfolds in different contexts (see, especially, Fainstein, 2001). The finding that a key group of private sector elites views their capacity in the development process as more limited than existing theories of urban power might predict lends additional support for a growing body of research underscoring the limited utility of the growth machine as a framework for understanding processes of local economic development, especially outside of the United States (see, e.g., DiGaetano and Klemanski, 1999; Jonas and Wilson, 1999; Savitch and Kantor, 2002; Wood, 2004).

\section{Acknowledgment}

An early draft of this article was presented at the annual meeting of the American Sociological Association in San Francisco in 2009. I would like to thank the session organizer and discussant, Mark Warren, for his helpful feedback and encouragement. This article also benefited greatly from comments and suggestions provided by Liza Weinstein, Hilary Silver, and the anonymous City $\mathcal{E}$ Community reviewers.

\section{Notes}

\footnotetext{
${ }^{1}$ For an informative historical account of the role played by individual private developers and real estate executives in urban land development, see Weiss (1987). The author's case study of Los Angeles in the early decades of the $20^{\text {th }}$ century outlines the extent to which conflicts and cooperation among groups of community builders and urban planners laid the groundwork for many of the land use practices and policies central to the suburbanization of the United States.

${ }^{2}$ Other scholars, embracing the relatively new "neopluralist" paradigm, have also introduced the notion of "power with," and consider how it operates apart from and in relation to "power over" and "power to" (McFarland, 2004; McFarland, 2006).

${ }^{3}$ These interviews constituted the second phase of a larger research project on firm location decisions and their implications for cities. In the first phase-a broad survey of over 200 real estate professionals on the factors that influence firm location decisions - respondents were asked whether they would agree to be contacted for a follow-up discussion. Out of 231 survey respondents, 83 (46 percent) indicated a willingness to be interviewed. I sent an email to each of these individuals, requesting an hour of his or her time. Ultimately, I conducted interviews with a subset of 30 of these respondents.

${ }^{4}$ Total exceeds 15 because several respondents mentioned more than one project type as their primary business.

${ }^{5}$ The characteristics of the Service Providers and End Users interviewed for this study very closely matched the characteristics of the overall sample of 231 survey respondents from which the interview sample was drawn.
} 
The only notable differences were that there were more Service Providers from the Central states in the interview sample (33 percent) than in the survey sample (20 percent), and fewer End Users working in finance/insurance in the interview sample (20 percent) than in the survey sample (34 percent).

${ }^{6}$ Since the interviewees were spread out all over the United States, all but three of the interviews were conducted over the phone. The remaining three were conducted in person, at the respondent's office. Each interview was tape recorded and transcribed. I requested permission to tape record each interview. No one declined. All respondents were assured that responses would be kept confidential and that no identifying names or specific projects would be revealed.

${ }^{7}$ This interpretation is in some ways an artifact of language choice. Indeed, much has been written about the tensions inherent in growth machines, and the constraints placed upon them by outside actors (e.g., anti-growth coalitions) or broader structural dynamics (e.g., the internationalization of capital) (Molotch and Logan, 1984). Accordingly, as increased attention focuses on how members of the growth machine reduce, manage, eliminate, or avoid those constraints (see, for example, Schneider and Teske, 1993; Warner and Molotch, 1995), the term "growth coalition," less suggestive of seamless, routinized operation, has become a common alternative (see, e.g., Gendron and Domhoff, 2009).

${ }^{8}$ In particular, the bureaucratic "Catch-22" describes how an increase in rules often leads to greater complexity, which in turn reduces coordination, resulting in the creation of contradictory rules and a decrease in overall efficiency (Merton, 1957).

${ }^{9}$ While there is debate concerning how much power New York City's 59 community boards actually hold, their actions continue to make headlines in the popular media. Most recently, attention has focused on the boards' role in stalling, complicating, or preventing liquor license approvals for certain restaurants (see, e.g., Faherty, 2008; Collins, 2009; Hennessy, 2009).

\section{References}

Bullard, R. 2000. Dumping in Dixie: Race, Class, and Environmental Quality, $3^{\text {rd }}$ Edition. Boulder, CO: Westview Press.

Canan, P., and Hennessy, M. 1989. "The Growth Machine, Tourism, and the Selling of Culture." Sociological Perspectives 32(2), 227-243.

Castells, M. 1977. The Urban Question. Cambridge, MA: MIT Press.

Clark, T., and Goetz, E. 1994. "The Anti-growth Machine: Can City Governments Control, Limit, or Manage Growth?” in T. Nichols (ed.), Urban Innovations: Creative Strategies for Turbulent Times, pp. 105-145. Thousand Oaks, CA: Sage.

Clingermayer, J., and Feiock, R. 1990. "The Adoption of Economic Development Policies by Large Cities: A Test of Economic, Interest Group, and Institutional Explanations.” Policy Studies Journal 18(3), 539-552.

Cole, L., and Foster, S. 2000. From the Ground Up: Environmental Racism and the Rise of the Environmental Justice Movement. New York: NYU Press.

Collins, G. 2009. "Liquor License Delays Lead to Restaurants' Pain.” The New York Times. August 4. Retrieved July 7, 2010. (http://www.nytimes.com/2009/08/05/dining/05lice.html?pagewanted=all)

Cox, K., and Mair, A. 1989. "The Urban Growth Machine and the Politics of Local Economic Development." International Journal of Urban and Regional Research 13(1), 137-146.

Cummings, S. 1988. Business Elites and Urban Development. Albany, NY: State University of New York Press.

Dahl, R. 1961. Who Governs? New Haven: Yale University Press.

DiGaetano, A., and Klemanski, J. 1999. Power and City Governance: Comparative Perspectives on Urban Development. Minneapolis: University of Minnesota Press.

Domhoff, G.W. 2006. "The Limitations of Regime Theory." City E Community 5(1), 47-51.

Elkin, S. 1985. "Twentieth Century Urban Regimes." Journal of Urban Affairs 7(2), 11-28.

Elkin, S. 1987. City and Regime in the American Republic. Chicago: University of Chicago Press.

Elkins, D. 1995. "The Structure and Context of the Urban Growth Coalition: The View From the Chamber of Commerce." Policy Studies Journal 23(4), 583-600. 


\section{CITY \& COMMUNITY}

Faber, D., and Krieg, E. 2005. Unequal Exposure to Ecological Hazards 2005: Environmental Injustices in the Commonwealth of Massachusetts. Produced by the Philanthropy and Environmental Justice Research Project, Northeastern University, Boston, MA (October 12).

Faherty, C. 2008. "Restaurateur's Difficulties Point to Community Board Trend." The New York Sun. March 13. Retrieved July 7, 2010. (http://www.nysun.com/new-york/restaurateurs-difficulties-point-tocommunity/72844/)

Fainstein, N., and Fainstein, S. 1983. "Regime Strategies, Communal Resistance, and Economic Forces." in S. Fainstein \& N. Fainstein (eds.), Restructuring the City, pp. 245-282. New York: Longman.

Fainstein, S. 2001. The City Builders: Property Development in New York and London, 1980-2000. Lawrence, KS: University Press of Kansas.

Gans, H. 1962. The Urban Villagers. New York: Free Press.

Gendron, R. 2006. "Forging Collective Capacity for Urban Redevelopment: 'Power To,' 'Power Over,' or Both?” City E Community 5(1), 5-22.

Gendron, R., and Domhoff, G.W. 2009. The Leftmost City: Power and Progressive Politics in Santa Cruz. Boulder, CO: Westview Press.

Gill, A. 2000. "From Growth Machine to Growth Management: The Dynamics of Resort Development in Whistler, British Columbia." Environment and Planning 32(6), 1083-1103.

Hartman, C. 2002. City for Sale: The Transformation of San Francisco. Berkeley, CA: University of California Press.

Harvey, D. 1973. Social Justice and the City. Baltimore: Johns Hopkins University Press.

Hennessy, G. 2009. A New Fight Over New Bars. New York Nights. June 3. Retrieved July 7, 2010. (http://nynnews.blogspot.com/2009/06/new-fight-over-new-bars.html)

Horak, M. 2007. Governing the Post-Communist City: Institutions and Democratic Development in Prague. Toronto: University of Toronto Press.

Humphrey, C. 2001. "Disarming the War of the Growth Machines: A Panel Study." Sociological Forum 16(1), 99-121.

Jonas, A., and Wilson, D. 1999. The Urban Growth Machine: Critical Perspectives Two Decades Later. Albany, NY: The State University of New York Press.

Kimelberg, S. 2010. "Can We Seal the Deal?": An Examination of Uncertainty in the Development Process." Economic Development Quarterly 24(1), 87-96.

Krannich, R., and Humphrey, C. 1983. "Local Mobilization and Community Growth: Toward an Assessment of the 'Growth Machine' Hypothesis.” Rural Sociology 48 (1), 60-81.

Lauria, M. 1997. "Introduction: Reconstructing Urban Regime Theory.” in M. Lauria (ed.), Reconstructing Urban Regime Theory: Regulating Urban Politics in a Global Economy. Thousand Oaks, CA: Sage Publications.

Lofland, J., and Lofland, L. 1995. Analyzing Social Settings: A Guide to Qualitative Observation and Analysis. Belmont, CA: Wadsworth Publishing Company.

Logan, J., and Crowder, K. 2002. "Political Regimes and Suburban Growth, 1980-1990." City E् Community 1(1), $113-135$.

Logan, J., and Molotch, H. 2007. Urban Fortunes: The Political Economy of Place. Berkeley, CA: University of California Press.

Logan, J., Whaley, R., and Crowder, K. 1997. "The Character and Consequences of Growth Regimes: An Assessment of Twenty Years of Research.” Urban Affairs Review 32(5), 603-630.

Lyon, L., Felice, L., Perryman, M.R., and Parker, E.S. 1981. "Community Power and Population Increase: An Empirical Test of the Growth Machine Model.” American Journal of Sociology 86(6), 1387-1400.

McFarland, A. 2004. Neopluralism: The Evolution of Political Process Theory. Lawrence, KS: University Press of Kansas.

McFarland, A. 2006. "Comment: Power-Over, To, and With.” City E Community 5(1), 39-41.

Merton, R. 1957. Social Theory and Social Structure. Glencoe, IL: Free Press.

Mollenkopf, J. 1983. The Contested City. Princeton, NJ: Princeton University Press.

Molotch, H. 1976. "The City as a Growth Machine: Toward a Political Economy of Place." American Sociological Review 82(2), 309-330.

Molotch, H. 1988. "Strategies and Constraints of Growth Elites." in S. Cummings (ed.), Business Elites and Urban Development, pp. 25-48. Albany, NY: State University of New York Press.

Molotch, H., and Logan, J. 1984. "Tensions in the Growth Machine: Overcoming Resistance to Value-Free Development." Social Problems 31(5), 483-499.

National League of Cities. 2009. "Cities 101". Retrieved June 29, 2009, from National League of Cities. Website: http://www.nlc.org. 
Pulido, L. 2000. "Rethinking Environmental Racism: White Privilege and Urban Development in Southern California." Annals of the Association of American Geographers 90 (1), 12-40.

Rossi, P., and Dentler, R. 1961. The Politics of Urban Renewal. New York: Free Press.

Rubin, H. 1986. "Local Economic Development Organizations and the Activities of Small Cities in Encouraging Economic Growth.” Policy Studies Journal 14(3), 363-388.

Savitch, H.V., and Kantor, P. 2002. Cities in the International Marketplace. Princeton, NJ: Princeton University Press.

Schneider, M. 1992. "Undermining the Growth Machine: The Missing Link between Local Economic Development and Fiscal Payoffs.” Journal of Politics 54(1), 214-230.

Schneider, M., and Teske, P. 1993. "The Antigrowth Entrepreneur: Challenging the 'Equilibrium' of the Growth Machine." Journal of Politics 55(3), 720-736.

Stone, C. 1976. Economic Growth and Neighborhood Discontent: System Bias in the Urban Renewal Program of Atlanta. Chapel Hill, NC: University of North Carolina Press.

Stone, C. 1989. Regime Politics: Governing Atlanta, 1946-1988. Lawrence: University of Kansas Press.

Stone, C. 1993. "Urban Regimes and the Capacity to Govern: A Political Economy Approach." Journal of Urban Affairs 15(1), 1-28.

Stone, C. 2006. "Power, Reform, and Urban Regime Analysis." City Ẽ Community 5(1), 23-38.

Warner, K., and Molotch, H. 1995. "Power to Build: How Development Persists Despite Local Controls." Urban Affairs Review 30(3), 378-406.

Weber, M. [1922] 1978. Economy and Society: An Outline of Interpretive Sociology. Berkeley, CA: University of California Press.

Weiss, M. 1987. The Rise of the Community Builders. New York: Columbia University Press.

Wood, A. 1993. "Organizing for Local Economic Development: Local Economic Development Networks and Prospecting for Industry." Environment and Planning A 25(11), 1649-1661.

Wood, A. 1996. "Analysing the Politics of Local Economic Development: Making Sense of Cross-National Convergence." Urban Studies 33(8), 1281-1295.

Wood, A. 2004. "Domesticating Urban Theory: British Cities and the Limits to US Frameworks." Urban Studies $41(11), 2103-2118$.

\section{Dentro de la Máquina del Crecimiento: los Profesionales de Bienes Raíces y sus Percep- ciones sobre los Desafíos del Desarrollo Urbano (Shelley Kimelberg)}

\section{Resumen}

El marco teórico de la máquina del crecimiento urbano plantea que las élites se agrupan en coaliciones para promover y adoptar las políticas y prácticas que mejor respondan a sus intereses económicos y propulsen el crecimiento de la ciudad. Aunque numerosos académicos han examinado los alcances teóricos y empíricos de esta teoría, se sabe muy poco sobre las creencias y perspectivas de los actores individuales que forman parte de la máquina del crecimiento urbano. El presente estudio aborda este vacío en la literatura existente a través de entrevistas a profundidad para analizar las perspectivas subjetivas de un segmento de la máquina del crecimiento -los profesionales de bienes raíces. Los resultados del estudio muestran que dichos profesionales consideran que el ejercicio del poder al nivel local está menos coordinado, menos orientado al consenso y menos orientado hacia el crecimiento urbano de lo que sugiere la tesis de la máquina del crecimiento. Más específicamente, plantean que su propio poder y margen de actuación se ven limitados por cuatro factores: los intereses electorales de los políticos, los intereses profesionales de quienes trabajan en la oficina municipal de desarrollo económico, los procedimientos burocráticos y regulaciones de ordenamiento territorial y la movilización de los grupos y residentes de la comunidad. La conclusión del artículo aborda las implicaciones de este trabajo para la teoría política urbana incluyendo sugerencias para estudios futuros. 